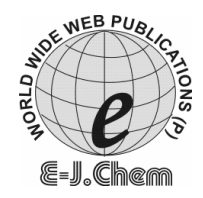

\title{
A New Validated RP- HPLC Method for the Determination of Nevirapine in Human Plasma
}

\author{
C H. VENKATA KUMAR, D. ANANTH KUMAR and \\ J. V. L. N. SESHAGIRI RAO* \\ Pharmaceutical Analysis and Quality Assurance Division, \\ A.U. College of Pharmaceutical Sciences, \\ Andhra University, Visakhapatnam - 530003, India. \\ jvlnsrao@ rediffmail.com
}

Received 9 November 2009; Accepted 5 January 2010

\begin{abstract}
A rapid, selective and sensitive high performance liquid chromatographic method for the estimation of nevirapine in human plasma has been developed. Chromatography was carried out on a Hypersil BDS $\mathrm{C}_{18}$ column using a mixture of ammonium acetate buffer $(\mathrm{pH} 4.0 \pm 0.05)$ and acetonitrile $(85: 15 \mathrm{v} / \mathrm{v})$ as the mobile phase. The eluents were monitored for the drug by UV detection at $254 \mathrm{~nm}$. Oxcarbazepine was used as an internal standard for this study. The retention times for nevirapine and oxcarbazepine were found to be 7.2 and $14.7 \mathrm{~min}$ respectively. The method was found to be linear in the concentration range of $50 \mathrm{ng} / \mathrm{mL}$ to $5003.7 \mathrm{ng} / \mathrm{mL}$. The method was validated as per FDA guidelines and was found to be suitable for bioequivalence and pharmacokinetic studies.
\end{abstract}

Keywords: Nevirapine, Determination, Plasma, HPLC.

\section{Introduction}

Nevirapine, chemically known as 1-cyclopropyl-5,11-dihydro-4-methyl-6H-dipyrido [3,2$\left.\mathrm{b}: 2^{\prime}, 3^{\prime}-\mathrm{e}\right][1,4]$ diazepin-6-one is a non-nucleoside reverse transcriptase inhibitor, active against herpes simplex virus type 1 and 2 and against viricella zoster virus ${ }^{1-2}$. It's a potent non-nucleoside reverse transcriptase inhibitor used in combination with nucleoside analogues for treatment of HIV infection and AIDS. Nevirapine binds directly to reverse transcriptase and blocks the RNA-dependent and DNA-dependent DNA polymerase activities by causing a disruption of the enzyme's catalytic site. It is official in USP and BP. Its empirical formula is $\mathrm{C}_{15} \mathrm{H}_{14} \mathrm{~N}_{4} \mathrm{O}$. The structure of nevirapine is shown in Figure 1. Literature survey reveals a few methods for the determination of nevirapine in various biological fluids and dosage forms by HPLC ${ }^{3-12}$. Methods based on GC-MS ${ }^{13}$, HPTLC ${ }^{14}$, 
LC-MS/MS ${ }^{15}$ and capillary electrophoresis ${ }^{16}$ for the determination of nevirapine are also reported. The authors now propose a sensitive, accurate and precise RP-HPLC method for the determination of nevirapine in human plasma.<smiles>Cc1ccnc2c1NC(=O)c1cccnc1N2C1CC1</smiles>

\section{Experimental}

Figure 1. Structure of nevirapine.

HPLC grade acetonitrile and methanol used in the study were obtained from Qualigens, India. HPLC grade water (milli Q) was prepared from Millipore (USA) equipment. Buffer was prepared by dissolving 2.312 grams of ammonium acetate in $1000 \mathrm{~mL}$ of milli-Q water. The $\mathrm{pH}$ of the buffer solution was adjusted to $4.0 \pm 0.05$ with acetic acid. The working standard samples of Nevirapine and Oxcarbazepine (internal standard) were obtained from Hereto Drugs (Hyderabad).

\section{Chromatographic conditions}

A Shimadzu HPLC equipment comprising of two LC-10AT VP pumps, VP CTO-10AS VP column oven, a Hypersil BDS $\mathrm{C}_{18}$ (4.6 ID x $150 \mathrm{~mm}, 5 \mu$ particle size) column and an SPD-10A variable-wavelength programmable UV-Visible detector was used for chromatographic separation. The detection of the compounds was monitored at $254 \mathrm{~nm}$. A mobile phase consisting of ammonium acetate buffer $(\mathrm{pH} 4.0 \pm 0.05)$ and acetonitrile in a ratio of 85:15 v/v was used at a rate of $1.2 \mathrm{~mL} / \mathrm{min}$. Data was acquired and processed with Class VP Software.

\section{Working standard solutions and the calibration curve}

The stock solution of the analyte was prepared in methanol at a free base concentration of $1 \mathrm{mg} / \mathrm{mL}$. The working standard solutions were prepared from the stock solution by using the mixture of methanol in water $(50: 50 \mathrm{v} / \mathrm{v}$ as diluent). These diluted working standard solutions were used to prepare the calibration curve standards and quality control samples. The solutions for obtaining the eight point standard calibration curve were prepared by spiking the screened blank plasma with appropriate amounts of nevirapine dilutions. The calibration curve was linear in the range of 50 to $5003.7 \mathrm{ng} / \mathrm{mL}(\mathrm{r} \geq 0.9900)$. The calibration plot was drawn with a weighing factor of $1 / \mathrm{X}^{2}$. The quality control samples were prepared at four concentration levels of $50.1 \mathrm{ng} / \mathrm{mL}$ (LLOQ QC), $150.1 \mathrm{ng} / \mathrm{mL}$ (LQC), $2011.8 \mathrm{ng} / \mathrm{mL}$ (MQC) and $3991.7 \mathrm{ng} / \mathrm{mL}$ (HQC).

The stock solution of the internal standard was prepared in a mixture of water and methanol $(80: 20 \mathrm{v} / \mathrm{v})$ at a free base concentration of $1 \mathrm{mg} / \mathrm{mL}$. From this, the working internal standard solution was prepared by suitable dilution with the above solvent mixture to contain $40 \mathrm{ng} / \mathrm{mL}$.

\section{Sample extraction procedure}

Five hundred micro liters of spiked plasma calibration curve standards and quality control samples were transferred to pre-labeled poly propylene tubes containing $50 \mu \mathrm{L}$ of internal standard. The tubes were vortexed for ten seconds. Each of the tubes was added $2.5 \mathrm{~mL}$ of extraction solvent (Ethyl acetate). The tubes were vortexed for 10 minutes at 2000 RPM on a 
vibramax unit and then were centrifuged at 4000 RPM for 5 minutes in a refrigerated centrifuge at $10{ }^{\circ} \mathrm{C}$ temperature. From the centrifuged polypropylene tubes approximately $2.0 \mathrm{~mL}$ of supernatant extracted solvent was transferred to a new set of pre-labeled polypropylene tubes. The contents of the tubes were evaporated in a stream of nitrogen at $40{ }^{\circ} \mathrm{C}$ for 10 minutes and the residues of the dried tubes were reconstituted with $0.2 \mathrm{~mL}$ mobile phase. The contents of the tubes were vortexed and transferred into auto-sampler vials and then analyzed with HPLC unit by injecting $40 \mu \mathrm{L}$ of sample volume.

\section{Validation}

The proposed method has been validated ${ }^{17}$ for selectivity, sensitivity, linearity, precision, accuracy, recovery, stability and dilution integrity. Selectivity was determined by testing the different blank plasma samples (from different donors) for interference at the retention times of the analyte and the internal standard. Sensitivity was determined by analyzing six replicates of blank human plasma and the plasma spiked with the analyte at the lowest value in the calibration curve. The intra run and inter run accuracy was determined by replicate analysis $(n=6)$ of the quality control samples at each level and at the limit of quantification value (LOQ) that was derived from the sample batch. Inter run precision and accuracy of the calibration standards were computed from the six calibration curves used for assay validation. The calibration curve results were presented in Tables $1 \& 2$.

Table 1. Summary of calibration parameters.

\begin{tabular}{cccc}
\hline Calibration curve & Slope & Intercept & Correlation coefficient \\
\hline 1 & 0.00110 & 0.00110 & 0.9951 \\
2 & 0.00007 & 0.00392 & 0.9985 \\
3 & 0.00008 & -0.00250 & 0.9986 \\
4 & 0.00008 & -0.00009 & 0.9902 \\
5 & 0.00008 & -0.00122 & 0.9996 \\
6 & 0.00007 & 0.00481 & 0.9962 \\
\hline
\end{tabular}

Table 2. Precision of plasma calibration curve standards $(n=6)$.

\begin{tabular}{cccc}
\hline $\begin{array}{c}\text { Nominal } \\
\text { concentration, ng/mL }\end{array}$ & $\begin{array}{c}\text { Mean } \\
\text { calculated concentration }\end{array}$ & $\begin{array}{c}\text { Percent } \\
\text { Coefficient variation }\end{array}$ & $\begin{array}{c}\text { Percent } \\
\text { Relative Error }\end{array}$ \\
\hline 50.0 & 50.75 & 10.5 & -1.42 \\
100.1 & 97.37 & 7.8 & 2.71 \\
250.2 & 250.65 & 7.3 & -0.19 \\
500.4 & 470.53 & 14.4 & 5.96 \\
1000.7 & 1023.85 & 8.2 & -2.31 \\
2001.5 & 1935.83 & 4.2 & 3.28 \\
4003.0 & 4146.90 & 8.6 & -3.60 \\
5003.7 & 4764.67 & 6.6 & 4.78 \\
\hline
\end{tabular}

Accuracy is defined as the percent relative $(\% \mathrm{RE})$ and was calculated using the formula $\% \mathrm{RE}=(\mathrm{E}-\mathrm{T}) \times(100 / \mathrm{T})$, were $\mathrm{E}$ is the experimentally determined concentration and $\mathrm{T}$ is the theoretical concentration of the drug. Assay precision was calculated using the formula $\% \mathrm{RSD}=(\mathrm{SD} / \mathrm{M}) \times(100)$ were $\mathrm{M}$ is the mean of the experimentally determined concentration and SD is standard deviation of $\mathrm{M}$. The precision and accuracy batch results were presented in Table 3. Dilution integrity was performed with samples falling above the upper concentration limits of the calibration curve. For this, a concentration of double the uppermost calibration standard was diluted two fold and four fold with blank plasma. Six replicates each of the diluted samples were processed and analyzed for accuracy and precision. 
Table 3. Precision and accuracy.

\begin{tabular}{|c|c|c|c|c|c|c|c|c|}
\hline \multirow[b]{2}{*}{ QC ID } & \multirow[b]{2}{*}{$\begin{array}{c}\text { Nominal } \\
\text { concentration, } \\
\text { ng/mL }\end{array}$} & \multicolumn{3}{|c|}{ Intra batch } & \multicolumn{4}{|c|}{ Inter batch } \\
\hline & & & $\begin{array}{c}\text { Mean } \\
\text { concentration } \\
\text { observed, } \mathrm{ng} / \mathrm{mL}\end{array}$ & $\stackrel{\%}{\mathrm{CV}} \% \mathrm{RE}$ & $\mathrm{n}$ & $\begin{array}{c}\text { Mean } \\
\text { concentration } \\
\text { observed, ng/mL }\end{array}$ & $\begin{array}{c}\% \\
\mathrm{CV}\end{array}$ & $\% \mathrm{R}$ \\
\hline$\overline{\text { LLOQ QC }}$ & 50.1 & 6 & 49.28 & $\begin{array}{ll}9.8 & 1.68\end{array}$ & 36 & 52.63 & 6.1 & -2.96 \\
\hline LQC & 150.1 & 6 & 150.17 & $6.3-0.06$ & 36 & 154.35 & 4.2 & -0.47 \\
\hline MQC & 2011.8 & 6 & 2094.47 & $3.9-4.11$ & 36 & 2051.70 & 4.4 & -3.16 \\
\hline HQC & 3991.7 & 6 & 3980.83 & 4.00 .27 & 36 & 4092.53 & 4.7 & 0.14 \\
\hline
\end{tabular}

The auto sampler or wet extracted stability of the processed sample was evaluated by comparing the extracted plasma samples that were injected immediately (comparison samples, $\mathrm{t}_{0}$ ), with the samples that were injected after keeping in auto-sampler at $10{ }^{\circ} \mathrm{C}$ for $30.0 \mathrm{~h}$ (stability samples). The stability of spiked human plasma samples stored at room temperature (Bench top stability) was evaluated for a period of eight hours and compared with that of the freshly prepared samples. The freeze-thaw stability was assessed by comparing the stability of the samples that had been frozen and thawed three times, with that of the freshly spiked quality control samples. The stability of spiked human plasma stored at $-70{ }^{\circ} \mathrm{C}$ (long - term stability) was evaluated by analyzing the quality control samples that were stored at $-70{ }^{0} \mathrm{C}$ for eight days together with the freshly spiked calibration standards and the quality control samples. All stability evaluations were based on back-calculated concentrations. The stability data is presented in Table 4. Analytes were considered stable if the deviations of the mean test responses were within $15 \%$ of the freshly prepared or comparison samples.

Table 4. Stability data.

\begin{tabular}{lccccc}
\hline $\begin{array}{c}\text { Details of } \\
\text { Stability } \\
\text { Experiment }\end{array}$ & $\mathrm{n}$ & $\begin{array}{c}\text { Spiked } \\
\text { concentration } \\
\mathrm{ng} / \mathrm{mL}\end{array}$ & $\begin{array}{c}\text { Mean calculated } \\
\text { comparison sample } \\
\text { concentration }\end{array}$ & $\begin{array}{c}\text { Mean calculated } \\
\text { stability sample } \\
\text { concentration }\end{array}$ & $\begin{array}{c}\text { Mean } \\
\text { percent } \\
\text { change }\end{array}$ \\
\hline $\begin{array}{l}\text { Bench top } \\
\text { stability HQC }\end{array}$ & 6 & 3991.7 & 3939.10 & 3729.03 & 5.63 \\
$\begin{array}{l}\text { Bench top } \\
\text { stability LQC }\end{array}$ & 6 & 150.1 & 150.83 & 145.90 & 3.38 \\
$\begin{array}{l}\text { Auto-sampler } \\
\text { stability HQC }\end{array}$ & 6 & 3991.7 & 4062.17 & 3963.65 & 2.49 \\
$\begin{array}{l}\text { Auto-sampler } \\
\text { stability LQC }\end{array}$ & 6 & 150.1 & 149.93 & 156.83 & -4.40 \\
$\begin{array}{l}\text { Freeze-thaw } \\
\text { stability HQC }\end{array}$ & 6 & 3991.7 & 3939.10 & 3958.25 & -0.48 \\
$\begin{array}{l}\text { Freeze-thaw } \\
\text { stability LQC }\end{array}$ & 6 & 150.1 & 150.83 & 151.92 & -0.71 \\
$\begin{array}{l}\text { Dry extract } \\
\text { stability HQC }\end{array}$ & 6 & 3991.7 & 4062.17 & 3931.98 & 3.31 \\
$\begin{array}{l}\text { Dry extract } \\
\text { stability LQC }\end{array}$ & 6 & 150.1 & 149.93 & 153.43 & -2.28 \\
$\begin{array}{l}\text { Long term } \\
\text { stability HQC }\end{array}$ & 6 & 3991.7 & 4122.60 & 3849.63 & 7.09 \\
$\begin{array}{l}\text { Long term } \\
\text { stability LQC }\end{array}$ & 6 & 150.1 & 157.17 & 148.32 & 5.97 \\
\hline
\end{tabular}


The representative chromatogram obtained from processing of blank plasma (Figure 3) shows that the assay procedure is specific as there was no interfering peaks were observed in the blank plasma at retention times corresponding to the drug and the internal standard.

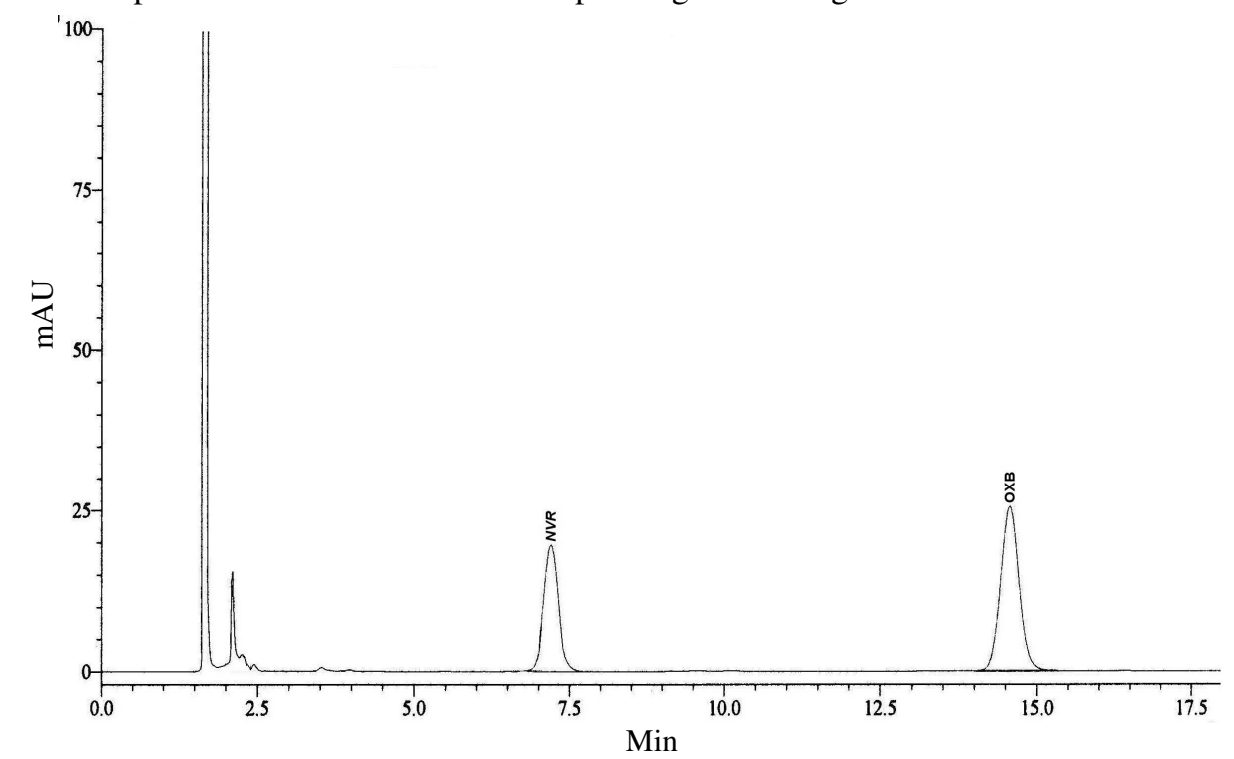

Figure 2. Representative chromatogram of nevirapine extracted from plasma.

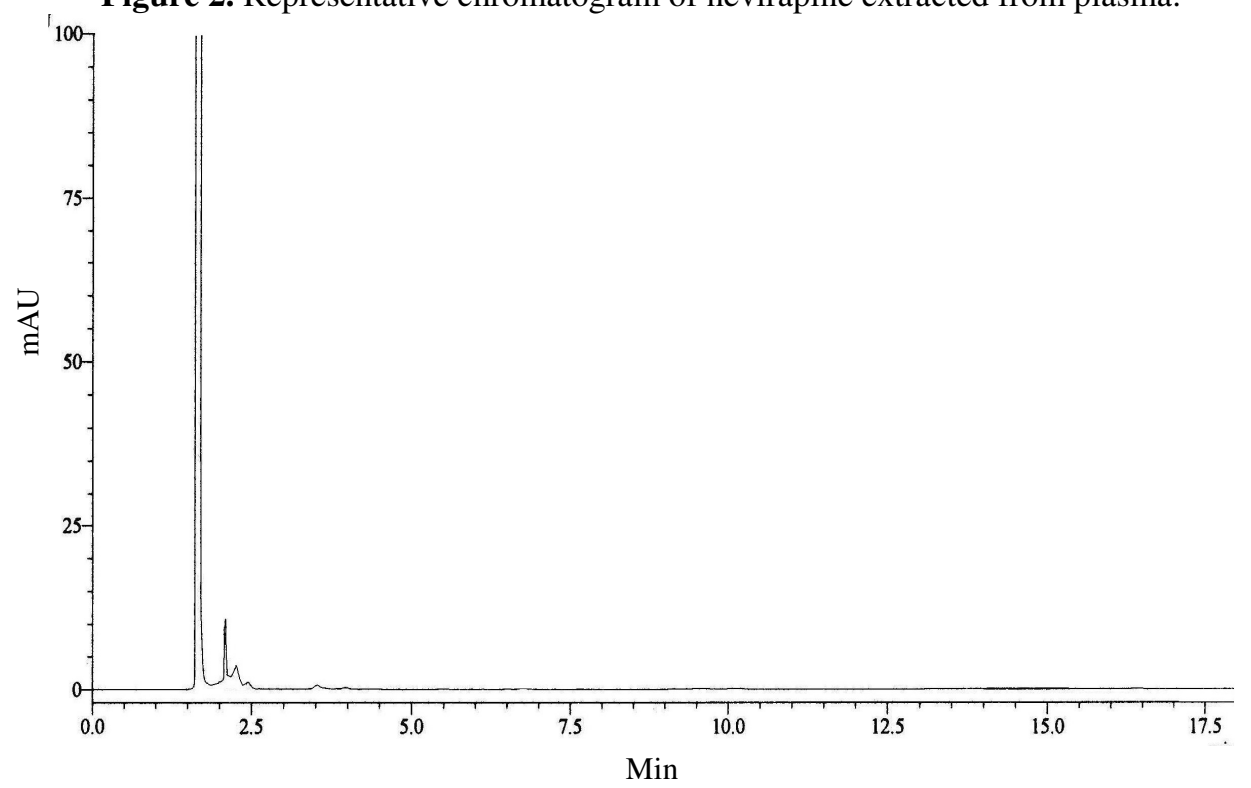

Figure 3. Representative chromatogram of extracted blank plasma sample.

\section{Conclusion}

The proposed validated HPLC method is simple, selective, precise and accurate for quantification of nevirapine in human plasma. The method may be useful for bio-availability and bio-equivalence studies on the drug. 


\section{References}

1. http://www.rxlist.com/cgi/generic/nevira.htm

2. Susan B, Maryadele Jo N, Ann S, Patricia E, Hecklemen and Joanne F K, The Merck Index. $13^{\text {th }}$ Ed., Monograph No.147, Merck, USA, 2001.

3. Bin F and Stewart J T, J Pharm Biomed Anal., 2002, 30, 955.

4. Emilia M, Luisa V, Roberta P, Manuela P, Gianna T and Piergiorgio Z, J Pharm Biomed Anal., 2002, 29, 1081.

5. Daillya E, Raffib F and Jollieta P, J Chromatogr B., 2004, 813, 353.

6. Pav J W, Rowland L S and Korpalski D J, J Pharm Biomed Anal., 1999, 20, 91.

7. $\quad$ Bin F and Stewart J T, J Pharm Biomed Anal., 2002, 28, 903.

8. Palaniappan M, DebKumar S, Tirthankar C and Karunakaran G, E Journal of Chemistry, 2008, 5(S2), 1081.

9. Naser Rezk L, Richard T R and Angela K D M, J Chromatogr B., 2003, 791, 137.

10. Aymard G, Legrand M, Trichereau N and Diquet B, J Chromatogr B., 2000, 744, 227.

11. Stefania N, Alessio B, Giuseppe I, Pasquale N, Leopoldo P P, Gianna T, Raffaele P D, Francesco G and Paolo A, J Chromatogr B., 2006, 831, 258.

12. Herve R, Bernard M, Corinne C and Pierre-Antoine B, J Chromatogr B., 2007, 850, 376.

13. Lemmer P, Schneider S, Schuman M, Omes C, Arendt V, Tayari J C, Fundira L and Wennig R, Ther Drug Monit., 2005, 27, 521.

14. Kaul N, Agrawal H, Paradkar A R and Mahadik K R, Talanta, 2004, 64, 843.

15. Stefania N, Carmine M, Tonino A, Marco T, Pasquale N and Paolo A, J Chromatogr B., 2008, 863, 249.

16. Elisabete P A, Gustavo M A and Marina T F M, J Chromatogr A., 2005, 1091, 169.

17. Guidance for Industry: Q2B Validation of Analytical Procedures, Methodology 1996. http:/www.fda.gov/cber/guidelines.htm 


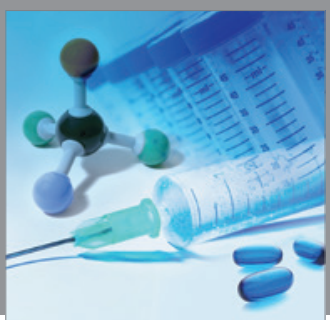

International Journal of

Medicinal Chemistry

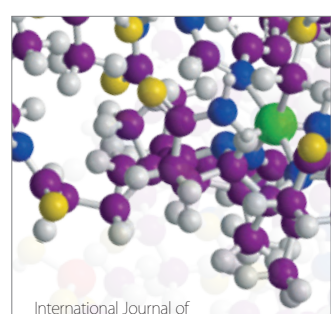

Carbohydrate Chemistry

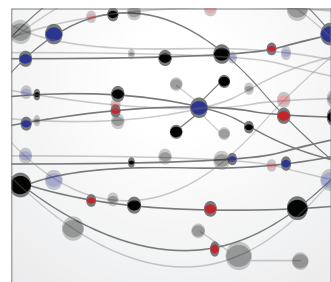

The Scientific World Journal
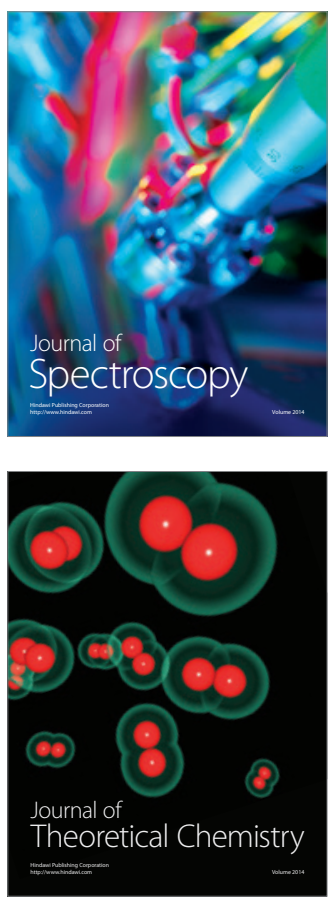
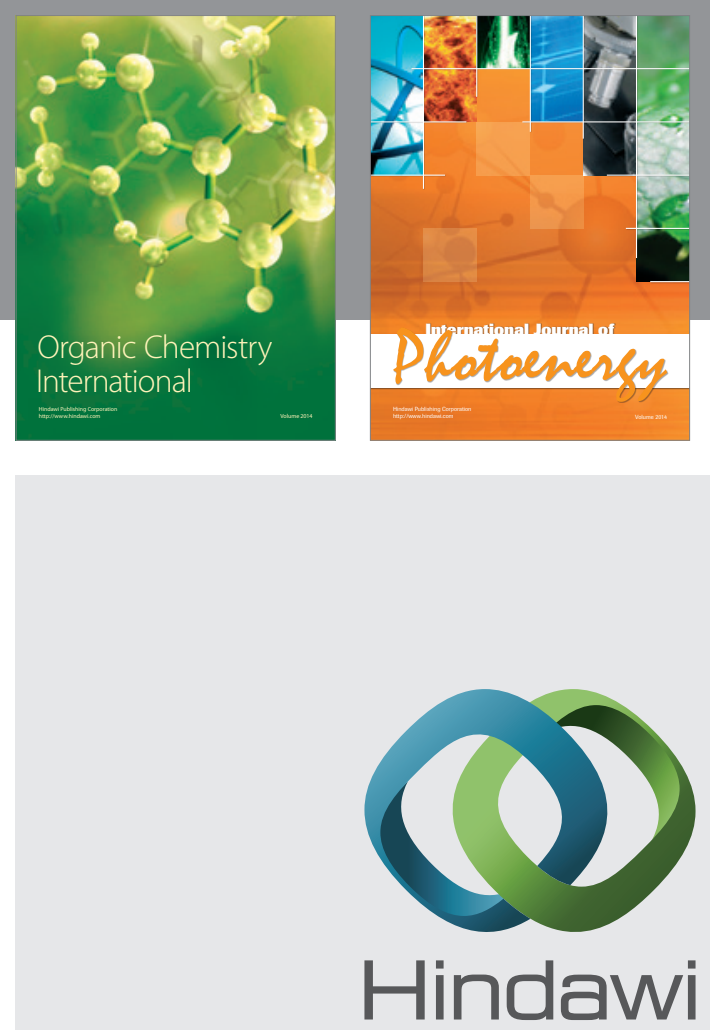

Submit your manuscripts at

http://www.hindawi.com
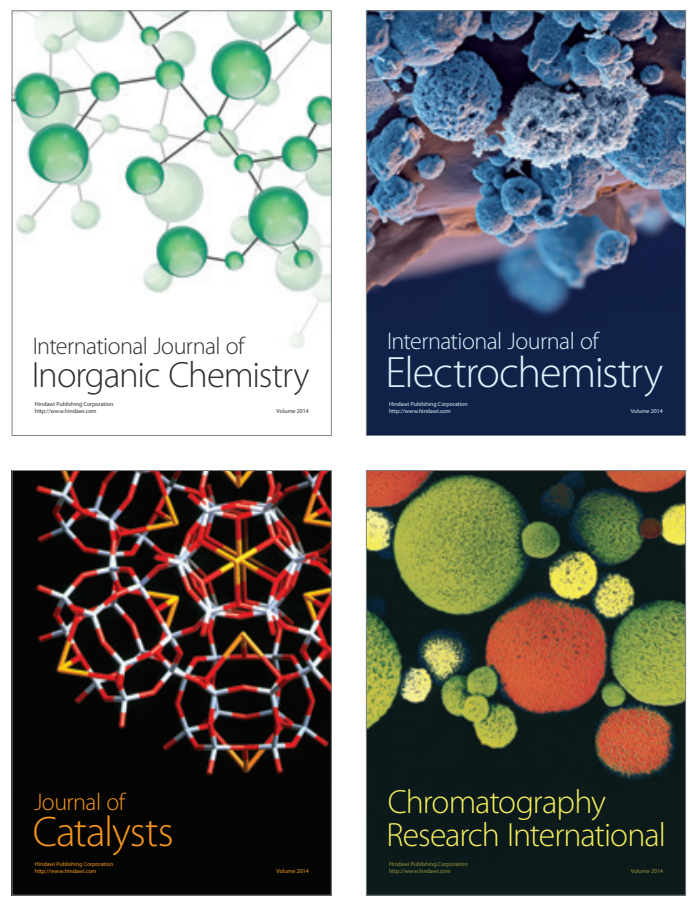
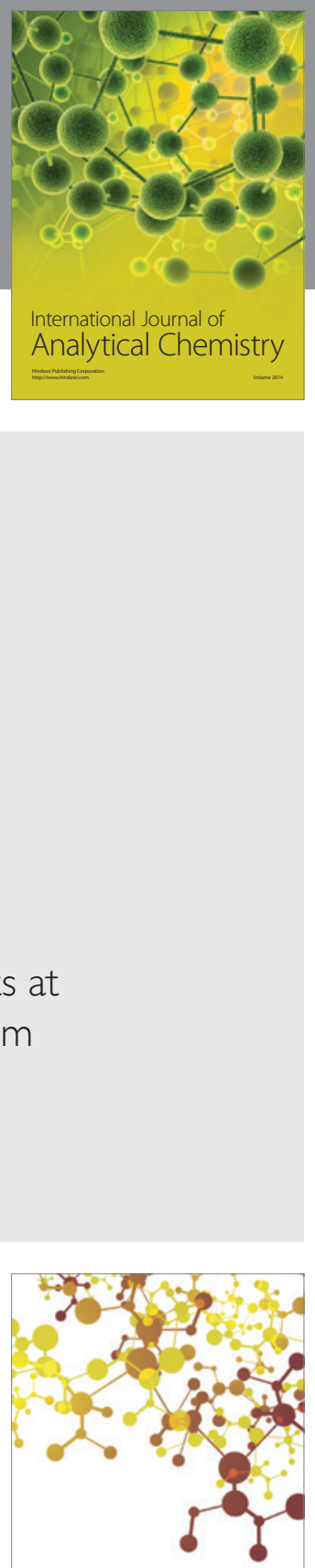

Journal of

Applied Chemistry
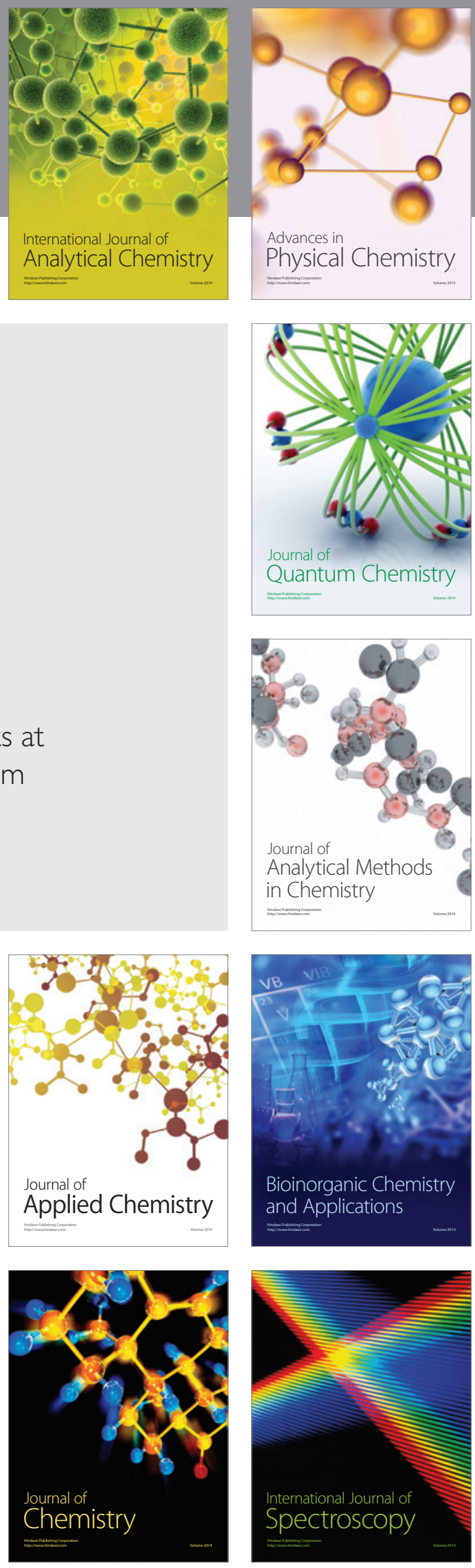